\title{
GIS BASED SOLAR POWER PLANTS SITE SELECTION USING ANALYTIC HIERARCHY PROCESS (AHP) IN ISTANBUL, TURKEY
}

\author{
A. Tunc *, G. Tuncay, Z. Alacakanat, F.S. Sevimli \\ ${ }^{1}$ ITU, Civil Engineering Faculty, 80626 Maslak Istanbul, Turkey - (tuncali1, tuncay15, alacakanat15, sevimli15)@itu.edu.tr
}

\author{
Commission IV, WG IV/10
}

KEY WORDS: Geographical Information Systems (GIS), Multi Criteria Decision Analysis, Analytical Hierarchy Process (AHP), Renewable Energy, Solar Power Plants, Site Selection

\begin{abstract}
:
Today, countries are shifting their energy policies towards to renewable energy sources. The main reasons for this can be summarized as the reduction of fossil fuel resources, resulting in cost increase and their harmful effect on the ecological balance. Since renewable energy sources are both economical and eco-friendly, for countries which have high solar energy potential such as Turkey, it is reasonable to direct their energy policies to solar energy which is a renewable energy source.

In this study, the development of renewable energy legislation in Turkey, from past to present has been examined and implementation steps for the licenced and unlicensed generation of electricity from solar energy have been introduced. Ten impact factors have been identified as the first step for the implementation of the solar power plant site selection in Istanbul, which was determined as the pilot region. Impact factors weighted using Analytical Hierarchy Process (AHP) method. Concurrently, the weights of these determined impact factors were compared with the weights obtained by evaluating the results of the "Evaluation of Solar Energy Power Plant Site Selection Factors" survey conducted during the study. After obtaining the weights, the relevant data were collected and the necessary analyses were performed with the help of the GIS software and the most suitable places were provided for the solar power plant for Istanbul.
\end{abstract}

\section{INTRODUCTION}

The concept of renewable energy refers to the energy that is constantly running in the environment (Jackson, 2000). Renewable energy sources include wind, solar, hydraulic, geothermal, biomass and marine. The biggest advantages of renewable energy can be defined as, minimizing the harm to the environment and reducing the dependence on foreign countries by offering the countries the opportunity to produce their own energy with domestic resources. When all these advantages are taken into consideration, it is inevitable that the investments made in the energy sector will progress in renewable energy direction.

According to the data of Renewable Energy Policy for the 21st Century Network (REN21), when the investments in renewable energy are examined worldwide, it can be seen that the total investment for 2017 is $\$ 279.8$ billion and China is the leading investment country followed by USA, Japan, India and Germany. Significant investments in this area, especially in developed countries, shows that the advantages of renewable energy use are accepted worldwide. The region with the least use of renewable energy sources is the Middle East, the centre of fossil fuels (Selam, Özel and Arığlu, 2013).
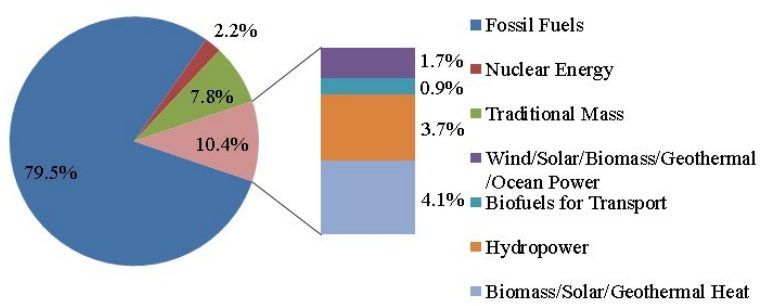

Figure 1. Total Energy Consumption (REN21, 2016)
In the Figure 1, the distribution of total energy consumption according to REN21 is given for 2016 globally. The share of fossil fuels is about $80 \%$ and the nuclear energy share is $2.2 \%$. The total share of renewable energy resources is $18.2 \%$ and the share of clean energy in all consumption approached to a fifth. By 2020 , it is estimated that $25 \%$ of the energy consumed in the world will be provided by renewable energy sources (Karagöl, Kavaz, 2017).

When assessing the current position, Turkey has significant energy resources and considered as a very rich country in terms of renewable energy sources. In recent years, Turkey has started to evaluate the opportunities in this field by focusing on solar energy and took steps to use its advantages. Solar energy is one of the most common renewable energy sources on earth, and therefore it offers more than other renewable energy sources. Solar energy can be used to obtain electricity and heat. This energy is divided into solar photovoltaic and solar thermal. Solar photovoltaic energy is the production of electricity by photovoltaic cells; and solar thermal energy, flat plate collectors and hot water, solar thermal - electricity plants can be explained as the production of electricity (Selam, Özel and Arıŏlu, 2013). In Turkey, considering as a developing country, energy needs are increasing every year. With the increase in energy demand, the increase in the installed capacity in Turkey has become inevitable. According to data of Electricity Transmission Company of Turkey (TEIAS), Turkey's installed power capacity reached 40,564.8 MW to 78,497.4 MW between 2006 to 2016 . In Figure 2, the installed power capacity of Turkey is given considering primary energy sources for 2006 and 2016. For the year 2016, hydraulic is the most widely used resource with a total installed power of $34 \%$, followed by natural gas with a rate of $24.92 \%$ and coal with a rate of $22.11 \%$. Solar energy sources constitute $1.06 \%$ of total power. 


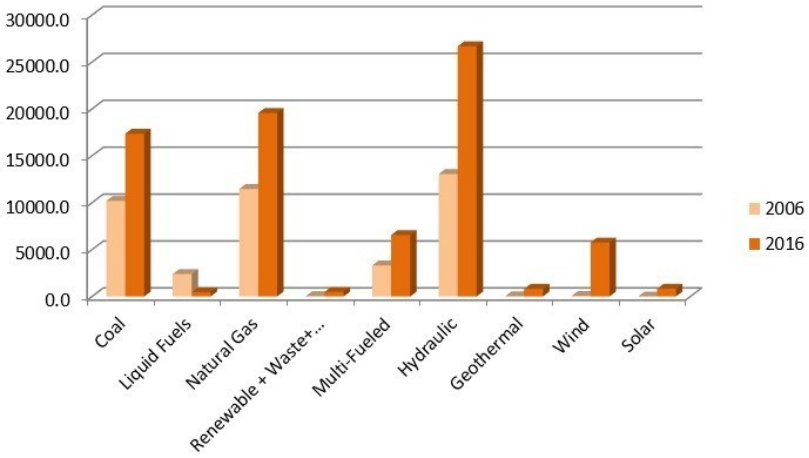

Figure 2. Installed Capacity by Primary Energy Source for the Years 2006 and 2016 (TEIAS, 2016)

In 2017, Turkey became one of the top 5 countries that invested the most in solar energy (REN21, 2018). The sunshine duration of Turkey according to the months are given in Figure 3. Average sunshine duration during the year varies between 3-4 hours and 10-12 hours. The total annual sunshine time is 2738 hours / year and the daily value is 7.5 hours / day. The theoretical solar power capacity of Turkey is $380 \mathrm{TWh} /$ year (Polat, Şekerci, 2011).

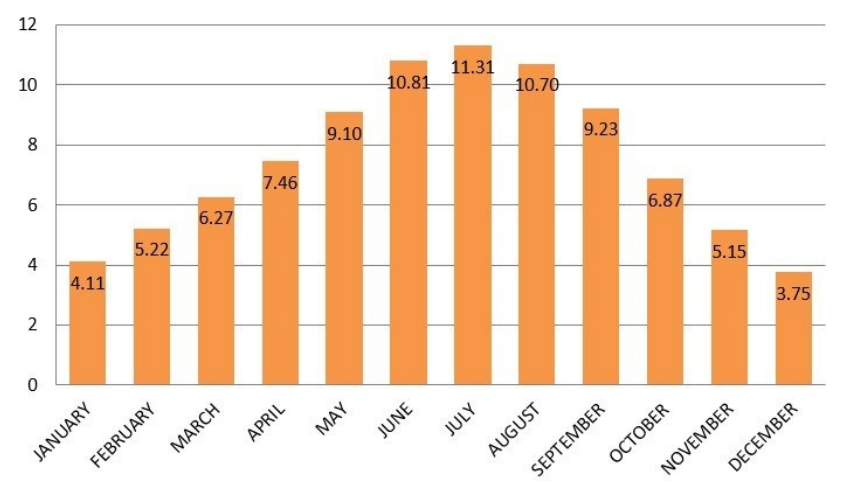

Figure 3. Sunshine Duration Per Month (General Directorate of Renewable Energy, 2017)

This study focuses on the selection, presentation and explanation of the steps to be followed for optimum locations for solar power plants in Istanbul, Turkey. It is a major challenge to provide energy to the population that is increasing rapidly every year, and the fact that the consciousness of renewable energy is not formed in the society and the process is not well recognized hampers the attempts for effective evaluation of the available resources. For this reason, potential areas suitable for interference are not known. Within the scope of the study to solve this problem, the legal process to be followed for the installation of the power plant was examined and the suitable places for the solar power plants were determined by using Multi Criteria Decision Making Method (MCDM). As known, MCDM methods are frequently used in recent years for the solution of site selection problems. In order to determine the best MCDM method to be used in this study, the literature review examined.

Asakreh et al. (2014), which aims to determine the most suitable location for solar energy systems, has determined the degree of conformity of the areas for the Shodirwan region of Iran with the Fuzzy-AHP method. Furthermore, Uyan (2016) conducted the study for Cumra district of Konya using the Analytical Hierarchy Method AHP method used in this study. In another Solar Power Plants (SPP) site selection study, Al Garni et al. (2017) preferred the same method for Saudi Arabia. Sindhu et al. (2017) conducted a case study of India with a hybrid solution using AHP and Fuzzy-TOPSIS methods together. Sánchez-Lozano et al. (2014) Using the ELECTRE-TRI method integrated with GIS, it has identified and classified areas suitable for photovoltaic solar farms in Spain. Akkas et al. (2017) In GES site selection; AHP, ELECTRE, TOPSIS, and VIKOR methods have applied to 5 different cities in Turkey and offer comparative results. In a different study, Uysal et al. (2014) used the ELECTRE method for the location problem of Logistics Center. As the literature review shows, MCDM is a very preferred solution for site selection problems. AHP is the most valid method for site selection within these solutions because it establishes the appropriate mathematical infrastructure to develop policies with site selection criteria.

After, the sample studies were examined, the consistency of the obtained results were compared with the other MCDM methods mentioned and spatial analyses were performed by using the weights obtained by AHP method which offers the best possible result.

\section{LEGAL ASPECTS OF SOLAR ENERGY IN TURKEY}

For the installation of the solar power plant and the location selection, it is necessary to examine the current legislation. Supporting the use of renewable energy sources in electricity production with the use of renewable energy sources and encouraging Turkey on behalf of the various legal arrangements have been made in the legislation (Erduman, Kekezoğlu, Durusu and Tanriöver, 2011). The first legal regulation on renewable energy issued in 2005 is the Law No. 5346. According to the law, electricity can be produced both as licensed and unlicensed by the sun, which is a renewable energy source.

There are fundamental differences between unlicensed production and licensed production. The first one is the production capacity. While the production capacity in licensed production is as explained in the license, the upper limit of the production capacity in unlicensed production is 1 megawatt. The second difference is the necessity of establishing a company. The persons who will operate in the licensed production market have the obligation to establish a company. In the case of unlicensed production, it is not obligatory to establish a company if the conditions specified in the regulation are met. The third difference is the application time. While application can be made on the dates set by the Energy Market Regulatory Authority for licensed production, there is no specific time criterion for applying to the relevant distribution company in unlicensed production (Law on Utilization of Renewable Energy Resources for the Purpose of Generating Electrical Energy, 2017).

In order to make licensed production at the solar power plant, the principles and procedures specified in a fundamental regulation should be followed, as well as other legal regulations and communiqués should be taken into consideration (Electricity Market Licencing Regulation, 2013). In order to generate licensed electricity, first the company should be established for electricity generation according to the Commercial Code No. 6102. One of the first steps that should be taken before taking the associate degree is the establishment of a solar measurement station approved by the General Directorate of Meteorology in the region where the plant will be established and taking measurements in the region. (Communiqué on Wind and Solar Measurements for Application of Wind and Solar Power Plant Pre-Licenses, 2014). For the application for associate degree, the documents which are determined by the Electricity Market Regulatory Authority are completed and applied to the Energy Market Regulatory Authority. A preliminary examination is carried out by the institution. 


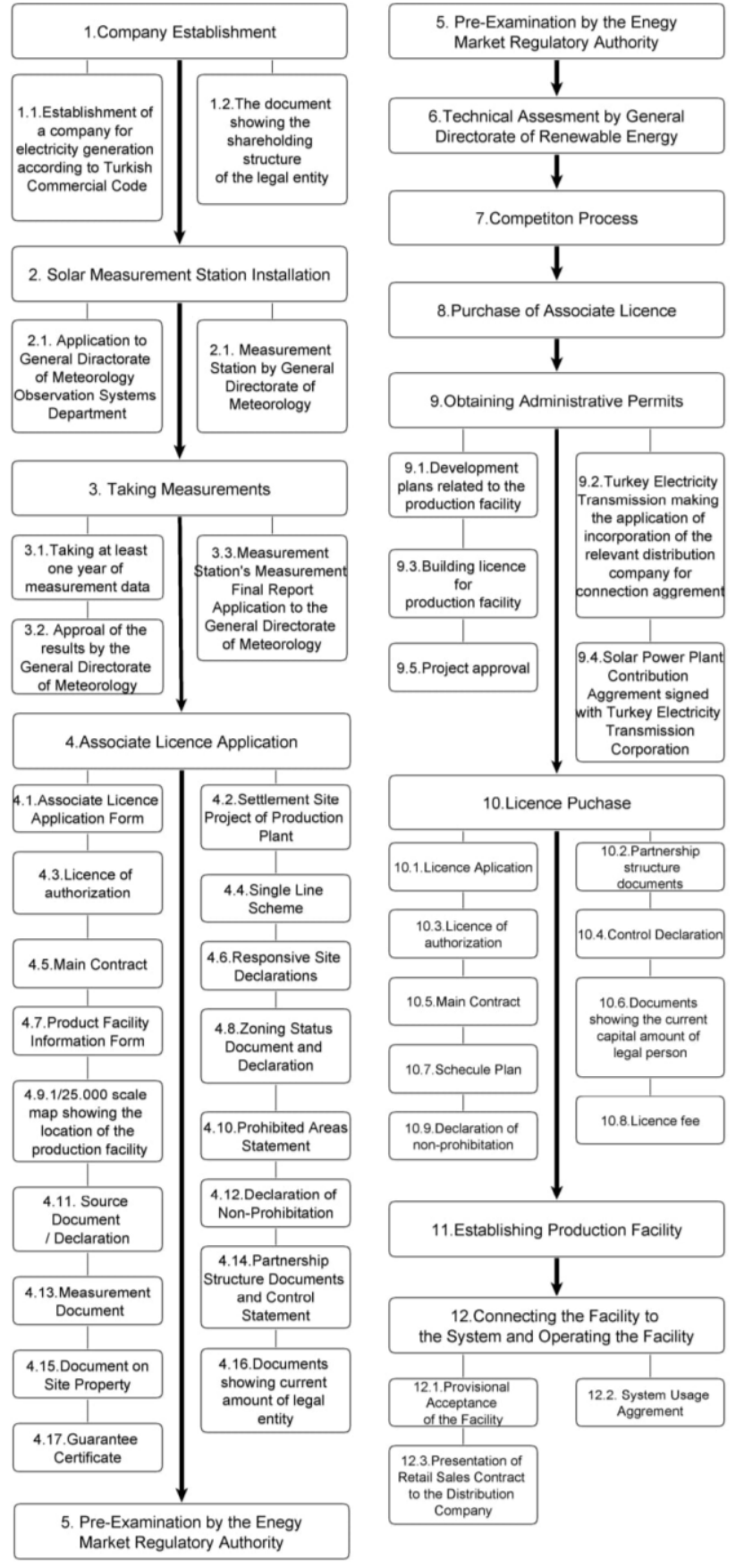

Figure 4. Implementation Steps for The Generation of Licenced Electricity from Solar Energy

The technical evaluation of the application is made by the General Directorate of Renewable Energy (Regulation on the Technical Evaluation of Applications for Generation of Electricity Based on Solar Energy, 2017). Connection permits are given to candidates who have passed the technical evaluation. If the facilities that want to connect to the same connection zone and there is not enough capacity, the ones who will connect to the system up to the capacity will be determined by Turkey Electricity Transmission Company (Regulation on Tender Rules for Application of Wind and Solar Power Plant Pre-Licenses, 2017). For the connection agreement, companies complete their application of associate degree to the Turkish Electricity Transmission Corporation or the related distribution company by completing the necessary administrative permissions. Companies apply for license with the documents issued by the Energy Market Regulatory Authority and then, they have obtained connection and system usage rights. Within the framework of these rights, the production license is deposited to the distribution company and the connection agreement is signed. After the partial or full provisional acceptance of the facility, the System Usage Agreement is signed and the facility is placed on the market (Regulation on Electricity Market Connection and System Usage, 2014). Figure 4 presents the implementation steps for the production of licensed electricity from solar energy.

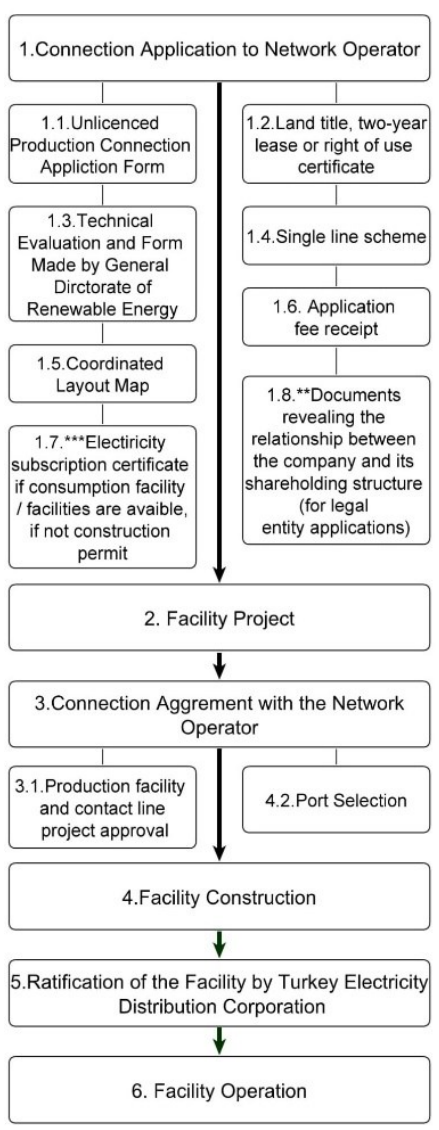

Figure 5. Application Steps for The Unlicensed Electricity Generation from Solar Energy

Principles and procedures for unlicensed electricity generation are determined by the regulation and the communiqué. Smallscale production facilities under legal regulation, including facilities with an installed capacity of up to 1 megawatt, are exempt from the obligation to obtain licenses. Unlicensed application starts with the application to the network operator. Once the documents in the regulation are completed, an application can be made to the distribution network. After the approval of the application and the technical evaluation made by the General Directorate of Renewable Energy, the project of the facility is prepared according to the provisions in the communiqué. The project is approved by the Ministry of Energy and Natural Resources or the institution authorized by the Ministry for the connection agreement. Within the scope of the rights obtained with the agreement, construction of the facility is started. (Regulation on Electricity Market Unlicensed Electricity Generation, 2013; Communiqué on Application of Regulation on Electricity Market Unlicensed Electricity Generation, 2012). Figure 5 shows the implementation steps for the production of unlicensed electricity from solar energy. 


\section{STUDY AREA AND DATA USED}

Within the framework of the paper, the site selection of solar power plants was determined for the chosen pilot region Istanbul, Turkey. In order to achieve maximum efficiency from the use of solar power plants and to minimize the negative effects that may arise from the plant, the places where these power plants should be constructed should be carefully selected. Criteria evaluated for appropriate site selection vary between similar studies. In other words, there are no clear rules for choosing suitable sites. In the process of determining the criteria discussed in this study, past studies and projects were examined, and ten appropriate solar power plant site selection criteria were determined. Using Analytical Hierarchy Process (AHP) from Multi-Criteria Decision Analysis methods, weights of the determined impact factors obtained.

In addition to AHP weighted data, "Evaluation of Solar Energy Power Plant Site Selection Factors" survey conducted during the study. The survey questions the importance's of selected factors introduced to experts and leading corporations in energy sector. The results of AHP weighting and the survey were compared. The results show that the weights determined by AHP are coherent with the weights obtained using results of the survey. For the second step, sub-criteria decision was made for each relevant factor. Determination of sub-criteria can be summarized as sorting the conditions under each factor from best probability to worse and ranking them. This ranked intervals and values enable determination of the best option when all factors used together and with their determined weights.

For the third step, the relevant data were collected from both state and the private sector channels, and the necessary analyses were performed with the help of the GIS software and the most suitable places were provided for the solar power plants. In the last part of the study, the results are intersected with the empty lands in Istanbul and the areas that can be easily projected in the near future have been determined.

Solar Irradiance: Solar energy potential can be considered as one of the main factors that directly affects efficiency. The level of solar radiation, which is one of the influential factors in determining solar radiation potential, is directly proportional to the energy generated (Saner, 2015).

The annual total solar radiation value of the region, which is planned to establish an electricity generation plant based on solar energy, should be equal to or higher than $1620 \mathrm{KWh} / \mathrm{m}^{2}$ year (Uyan, 2016). This corresponds to approximately $4.5 \mathrm{kWh} / \mathrm{m}^{2}$ of radiation value on a daily basis. Within the scope of this study, this layer was formed by Global Direct Irradiance (GDI) and Global Horizontal Irradiance (GHI) data of the neighbourhoods located in Istanbul.

Sunshine Duration: Another value used to determine the potential of solar energy is the sunshine duration. The total annual sunshine time is 2738 hours / year and the daily value is 7.5 hours / day. The theoretical solar power capacity of Turkey is $380 \mathrm{TWh} /$ year. The sunshine duration layer obtained for the province of Istanbul was used as district based.

Temperature Ratio: Another factor that should be taken into consideration in the plant to be installed is the temperature ratio. The increase in the average temperature of the region causes a decrease in the efficiency of the photovoltaic systems. In these regions, if the system is desired to be installed, the use of the modules which are suitable for the high temperature value increases the cost (Saner, 2015).
In this respect, regions with high temperature values should not be preferred when choosing the location. The temperature layer was formed using district-based data in the same way as the sunshine duration layer.

Land Use: The use of property in the area where the power plant will be installed includes public and treasury lands, and it is of great importance to reduce the project cost and implement the project. Within the scope of the study, the desired layer was formed by using Istanbul property type map.

Distance to Other Renewable Energy Plants: Each connection zone has a certain capacity for renewable energy sources. If the capacity is full, no pre-license is granted. When there is more than one application for capacity in the same connection area, the contest is organized (Regulation on Tender Rules for Application of Wind and Solar Power Plant Pre-Licenses, 2017). The winner of the contest is given a pre-license. The proximity of the power plant to other renewable power plants means that they are connected to the same connection center. In this case, production is allowed up to the open capacity.

The capacity of the plants to be distant from each other allows the license to be taken. At this point, according to the subclasses determined in the vicinity of renewable energy power plants in the province of Istanbul, a buffer was formed by creating a layer for this criterion.

Distance to North Anatolian Fault: Even in the event of an accident, the release of toxins and refrigerants used in the plants carries a significant risk of creating significant environmental problems (Saner, 2015). It is clear that a normal natural disaster will always keep this risk at high levels. In order to eliminate or at least minimize this risk, site selection should be made as far as possible to earthquake fault lines. For the North Anatolian Fault Line, Istanbul Earthquake Risk Zoning was performed.

Distance to Objectionable and Prohibited Areas: Choosing a place within or near the area of influence of the prohibited areas specified in the Master Plans should be avoided. It is for this reason that 'Distance to Objectionable and Prohibited Areas' layer has been established for the prohibited areas in the Istanbul Master Plan.

Slope: The slope rate of $3 \%$ causes the cost increase, while $0 \%$ slopes cause water accumulation and drainage problems. Therefore, a slope layer has been formed within the scope of the study.

Wind Speed: The wide surfaces of the panels and reflectors used for energy production activities cause damage from the high speed winds. If the wind speed in the region exceeds 25-30 mps, the system may be damaged, so regions with high wind speeds should not be preferred (Miller, Lumby, 2012). For this reason, this layer has been formed within the scope of the study.

Distance to Energy Transmission Lines: When choosing the location for a solar power plant to be established, the distance of the project area to be selected from the energy transmission lines is also a factor. Excessive distance due to the need for new transmission lines creates additional costs and creates an adverse economic impact. The overlap between the power plant and the power plant is ideal. Large-scale power plants are not preferred to be within $10 \mathrm{~km}$ of the national network. In smaller and medium-sized production facilities, distances between 5 and 10 $\mathrm{km}$ to the national network are still not preferred in terms of economic efficiency of the investment. For this reason, this layer has been formed within the scope of the study (Saner, 2015). 


\subsection{Methodology}

The Analytic Hierarchy Process (AHP) is a theory of measurement with binary comparisons and is based on the opinions of experts to derive priority scales (Saaty, 2008).

By using the Analytic Hierarchy Method, the necessary actions for weighting the effect factors of a system with n-effect factors are discussed in this section before introducing the obtained impact factor weights of the study.

First, the decision-making problem should be determined. At this stage, the purpose, the criteria selected as the determinant to reach the result, and the options to choose from are determined and the hierarchy of the system to be solved is established in Figure 7.

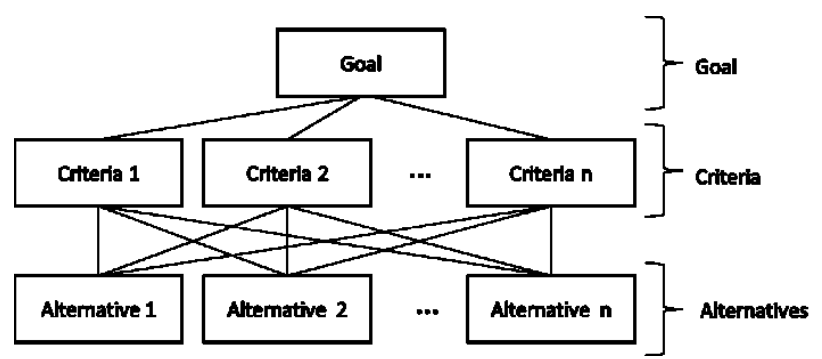

Figure 7. System Hierarchy

In the second step, double comparison matrixes are created for these criteria according to expert opinions. For the criterion n, a comparison matrix is written in size ( $\mathrm{n} \times \mathrm{n})(1)$.

$$
\mathrm{A}=\left[\begin{array}{cccc}
a_{11} & a_{12} & \ldots & a_{1 n} \\
a_{21} & & & \\
\vdots & \ddots & & \vdots \\
\vdots & & \ddots & \\
a_{n 1} & \ldots & & a_{n n}
\end{array}\right]
$$

Each element of this matrix is generated using the scaling given in Table-2. Accordingly, the $a_{i j}$ element is the result of the comparison of the criteria numbered $i$ and $j$. Each matrix element provides the equations $a_{i j}=\frac{1}{a_{j i}}$ and $a_{i i}=1$

\begin{tabular}{l|l} 
Intensity of Importance & Definition \\
\hline 1 & Equal Importance \\
\hline 3 & Moderate Importance \\
\hline 5 & Strong Importance \\
\hline 7 & Very Strong Importance \\
\hline 9 & Extreme Importance \\
$2,4,6,8$ & $\begin{array}{l}\text { Intermediary Values: Used } \\
\text { when preferences are close to } \\
\text { each other }\end{array}$
\end{tabular}

Table 2. Scale for binary comparison in AHP

In the next step, each $a_{i j}$ element is divided by the total of the column j. For each column of the newly formed normalized Aw matrix, the sum of the elements must be equal to 1 (2).

$$
A w=\left[\begin{array}{cccc}
\frac{a_{11}}{\sum a_{11}} & \frac{a_{12}}{\sum a_{i 2}} & \cdots & \frac{a_{1 n}}{\sum a_{i n}} \\
\frac{a_{21}}{\sum a_{11}} & & & \\
\vdots & \ddots & & \vdots \\
\vdots & & \ddots & \\
\frac{a_{n 1}}{\sum a_{i 1}} & \cdots & & \frac{a_{n n}}{\sum a_{i n}}
\end{array}\right]
$$

The arithmetic mean of the line elements of the normalized matrix is then calculated ( 3 ). These values determine the severity of the criteria as percentages.

$$
C=\left[\begin{array}{c}
c_{1} \\
c_{2} \\
\vdots \\
c_{n}
\end{array}\right]
$$

In the fourth step, the consistency of the benchmark comparisons is checked. For this, the matrix A x C must be calculated first. Then $\lambda_{\max }$ is calculated. (4)

$$
A x C=\left[\begin{array}{c}
x_{1} \\
x_{2} \\
\vdots \\
x_{n}
\end{array}\right], \quad \lambda_{\max }=\frac{1}{n} \sum_{i=1}^{n} \frac{x_{i}}{c_{i}}
$$

The Consistency Index (CI) is calculated as follows. Then the Random Consistency Index (RI) is found in Table-3, which is the number of criteria examined, and the Consistency Ratio (CR) is calculated using this value (5).

$$
C I=\frac{\lambda_{\max -n}}{n-1}, C R=\frac{C I}{R I}
$$

\begin{tabular}{|c|c|c|c|c|c|c|c|c|c|c|}
\hline $\mathbf{n}$ & $\mathbf{1}$ & $\mathbf{2}$ & $\mathbf{3}$ & $\mathbf{4}$ & $\mathbf{5}$ & $\mathbf{6}$ & $\mathbf{7}$ & $\mathbf{8}$ & $\mathbf{9}$ & $\mathbf{1 0}$ \\
\hline $\mathrm{RI}$ & 0 & 0 & 0.58 & 0.90 & 1.12 & 1.24 & 1.32 & 1.41 & 1.45 & 1.49 \\
\hline
\end{tabular}

Table 3. Random Consistency Index

For the calculated weights to be considered as consistent and usable, Consistency Ratio should provide the $\mathrm{CR}<0.1$ inequality.

\subsection{Determination of Weight Due to Survey}

"Evaluation of the Site Selection Impact Factors of the Solar Power Plant" survey was submitted to the opinion of experts who have knowledge, skills and knowledge in the field of solar energy and the participants were asked to indicate the importance of all factors in the given range for each factor.

\section{RESULTS}

Within the scope of the study, the impact of each criterion were analysed using the AHP. Firstly, system hierarchy has been established for weighting of the 10 criteria determined in the study.

Following the establishment of the System Hierarchy, a double comparison matrix was established, the related process steps were followed and the weights of the factors were calculated (Table 5). The Consistency Ratio (CR) of the factor weights was calculated as 0.064 . This value is below the limit value of 0.1 and means that the values found are available.

In this study, separate weightings were made by using Analytical Hierarchy Method and also survey results. The title distribution of the 45 participants was given in Figure 8 . The percentages were calculated for each of the 10 impact factors using the evaluations. 
Survey results and percent weights calculated using Analytical Hierarchy Method are given in Table-5. When examined, it is seen that the factors of 'Solar Irradiation Level' and 'Sunshine Duration' are the two most important factors in weighting by both methods. When the percentage weights of other factors are examined comparatively, it is observed that the values are generally consistent with each other. This means that the Analytical Hierarchy Method gives parallel results with the directions given by the professionals in energy sector in the determination of sites for Solar Power Plants.

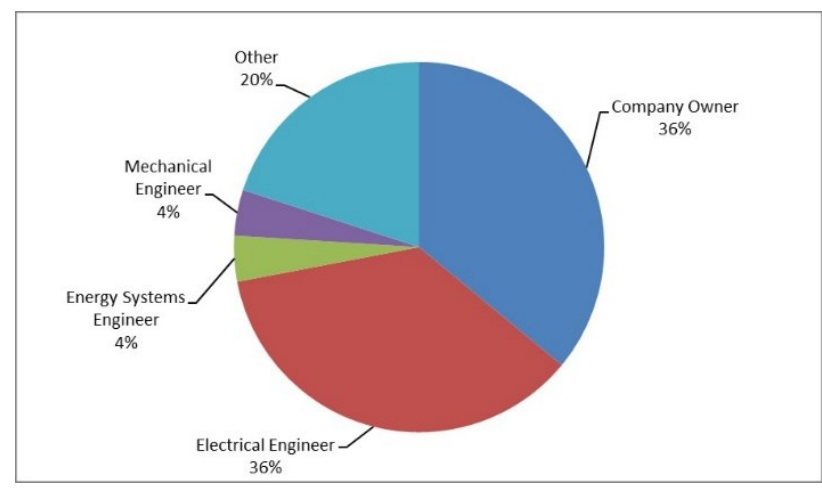

Figure 8. "Evaluation of Solar Power Plant Location Selection Impact Factors" Survey Participants and Distribution of Title

After calculating the weights with AHP, the weightage maps of the determined ten criteria is generated by reclassifying the classes. In order to create weightage maps, firstly the sub-criteria of the given criteria are determined as shown in Table 6, so that the data obtained for the province of Istanbul and the legal regulations discussed in the study will give a healthy result.

\begin{tabular}{|c|c|c|}
\hline Criteria & Weight (AHP) & Weight (Survey) \\
\hline Solar Irradiation Level & 13.26 & 13.082 \\
\hline Sunshine Duration & 13.26 & 13.053 \\
\hline Temperature Ratio & 9.81 & 10.499 \\
\hline Land Use & 12.69 & 11.152 \\
\hline $\begin{array}{c}\text { Distance to Other } \\
\text { Renewable Plants }\end{array}$ & 3.16 & 11.209 \\
\hline $\begin{array}{c}\text { Distance to North } \\
\text { Anatolian Fault }\end{array}$ & 9.79 & 11.209 \\
\hline $\begin{array}{c}\text { Distance to } \\
\text { Objectionable and } \\
\text { Prohibited Areas }\end{array}$ & 8.13 & 7.6617 \\
\hline Slope & 11.59 & 9.1657 \\
\hline Wind Speed & 7.46 & 4.2565 \\
\hline $\begin{array}{c}\text { Distance to Energy } \\
\text { Transmission Lines }\end{array}$ & 10.85 & 8.7117 \\
\hline
\end{tabular}

Table 5. Weights of Criteria (\%) with AHP and Survey

To conclude the most appropriate site analysis to be determined for the solar power plant to be established in Istanbul, in this study for the province of Istanbul, the factors used in making the most intensive literature survey with restrictions specified in the regulations of Turkey were evaluated. The weighted maps with the help of the 10 criteria presented in Figure 9.

The site selection analysis for the solar power plant in Istanbul was carried out with the help of the spatial analysis provided by the GIS. At this point, maps prepared according to the reclassification values set out in Table 6 are given in Figure 9 in order to give effective-conclusive results and to show the different effects of the criteria for the province of Istanbul. In summary, the results obtained with the data layers used as input in the study were classified according to their suitability for the Solar Power Plant and result maps were generated. For decision making on suitable site for solar power plants, integration of all the thematic layers and weightage values, as a composite map is required. The suitable site map for solar power plant is generated using ten weighted and reclassified criteria. The suitable sites are then categorised into three suitability categories (e.g. very suitable, suitable and less suitable). As a result of the study, the most suitable areas for solar power plants in the provincial border of Istanbul have been revealed.

\begin{tabular}{|c|c|c|c|}
\hline Weight (\%) & Criteria & \multicolumn{2}{|l|}{ Sub-Criteria } \\
\hline \multirow{4}{*}{13.26} & \multirow{4}{*}{$\begin{array}{c}\text { Solar } \\
\text { Irradiation } \\
\text { Level }\end{array}$} & $>2500 \mathrm{kWh} / \mathrm{m}^{2}$ & 1 \\
\hline & & $\begin{array}{c}1800-2500 \\
\mathrm{kWh} / \mathrm{m}^{2}\end{array}$ & 2 \\
\hline & & $\begin{array}{c}1500-1800 \\
\mathrm{kWh} / \mathrm{m}^{2}\end{array}$ & 3 \\
\hline & & $<1500 \mathrm{kWh} / \mathrm{m}^{2}$ & 4 \\
\hline \multirow{4}{*}{13.26} & \multirow{4}{*}{$\begin{array}{l}\text { Sunshine } \\
\text { Duration }\end{array}$} & $>6,9$ hours/day & 1 \\
\hline & & $\begin{array}{c}6,7-6,9 \\
\text { hours/day }\end{array}$ & 2 \\
\hline & & $\begin{array}{c}6,5-6,7 \\
\text { hours/day }\end{array}$ & 3 \\
\hline & & $<6,5$ hours/day & 4 \\
\hline \multirow{4}{*}{9.81} & \multirow{4}{*}{$\begin{array}{c}\text { Temperature } \\
\text { Ratio }\end{array}$} & $20-25{ }^{\circ} \mathrm{C}$ & 1 \\
\hline & & $15-20{ }^{\circ} \mathrm{C}$ & 2 \\
\hline & & $10-15^{\circ} \mathrm{C}$ & 3 \\
\hline & & $0-10^{\circ} \mathrm{C}$ & 4 \\
\hline \multirow{2}{*}{12.69} & \multirow{2}{*}{ Land Use } & State Property & 1 \\
\hline & & Others & 2 \\
\hline \multirow{4}{*}{3.16} & \multirow{4}{*}{$\begin{array}{l}\text { Distance to } \\
\text { Other } \\
\text { Renewable } \\
\text { Energy Plants }\end{array}$} & $>10000 \mathrm{~m}$ & 1 \\
\hline & & $6000-10000 \mathrm{~m}$ & 2 \\
\hline & & $3000-6000 \mathrm{~m}$ & 3 \\
\hline & & $<3000 \mathrm{~m}$ & 4 \\
\hline \multirow{4}{*}{9.79} & \multirow{4}{*}{$\begin{array}{l}\text { Distance to } \\
\text { North } \\
\text { Anatolian } \\
\text { Fault }\end{array}$} & $>50000 \mathrm{~m}$ & 1 \\
\hline & & $35000-50000 \mathrm{~m}$ & 2 \\
\hline & & $15000-35000 \mathrm{~m}$ & 3 \\
\hline & & $<15000 \mathrm{~m}$ & 4 \\
\hline \multirow{4}{*}{8.13} & \multirow{4}{*}{$\begin{array}{c}\text { Distance to } \\
\text { Objectionable } \\
\text { and } \\
\text { Prohibited } \\
\text { Areas }\end{array}$} & $>5000 \mathrm{~m}$ & 1 \\
\hline & & $2000-5000 \mathrm{~m}$ & 2 \\
\hline & & $500-2000 \mathrm{~m}$ & 3 \\
\hline & & $>500 \mathrm{~m}$ & 4 \\
\hline \multirow{4}{*}{11.59} & \multirow{4}{*}{ Slope } & $30^{\circ}-45^{\circ}$ & 1 \\
\hline & & $20^{\circ}-30^{\circ}$ & 2 \\
\hline & & $10^{\circ}-20^{\circ}$ & 3 \\
\hline & & $0^{\circ}-10^{\circ}$ & 4 \\
\hline \multirow{4}{*}{7.46} & \multirow{4}{*}{ Wind Speed } & $<20$ mps & 1 \\
\hline & & $20-25 \mathrm{mps}$ & 2 \\
\hline & & $25-30 \mathrm{mps}$ & 3 \\
\hline & & $>30 \mathrm{mps}$ & 4 \\
\hline \multirow{4}{*}{10.85} & \multirow{4}{*}{$\begin{array}{l}\text { Distance to } \\
\text { Energy } \\
\text { Transmission } \\
\text { Lines }\end{array}$} & $<3000 \mathrm{~m}$ & 1 \\
\hline & & $3000-6000 \mathrm{~m}$ & 2 \\
\hline & & $6000-10000 \mathrm{~m}$ & 3 \\
\hline & & $>10000 \mathrm{~m}$ & 4 \\
\hline
\end{tabular}

Table 6. Reclassification of Weighted Criteria 


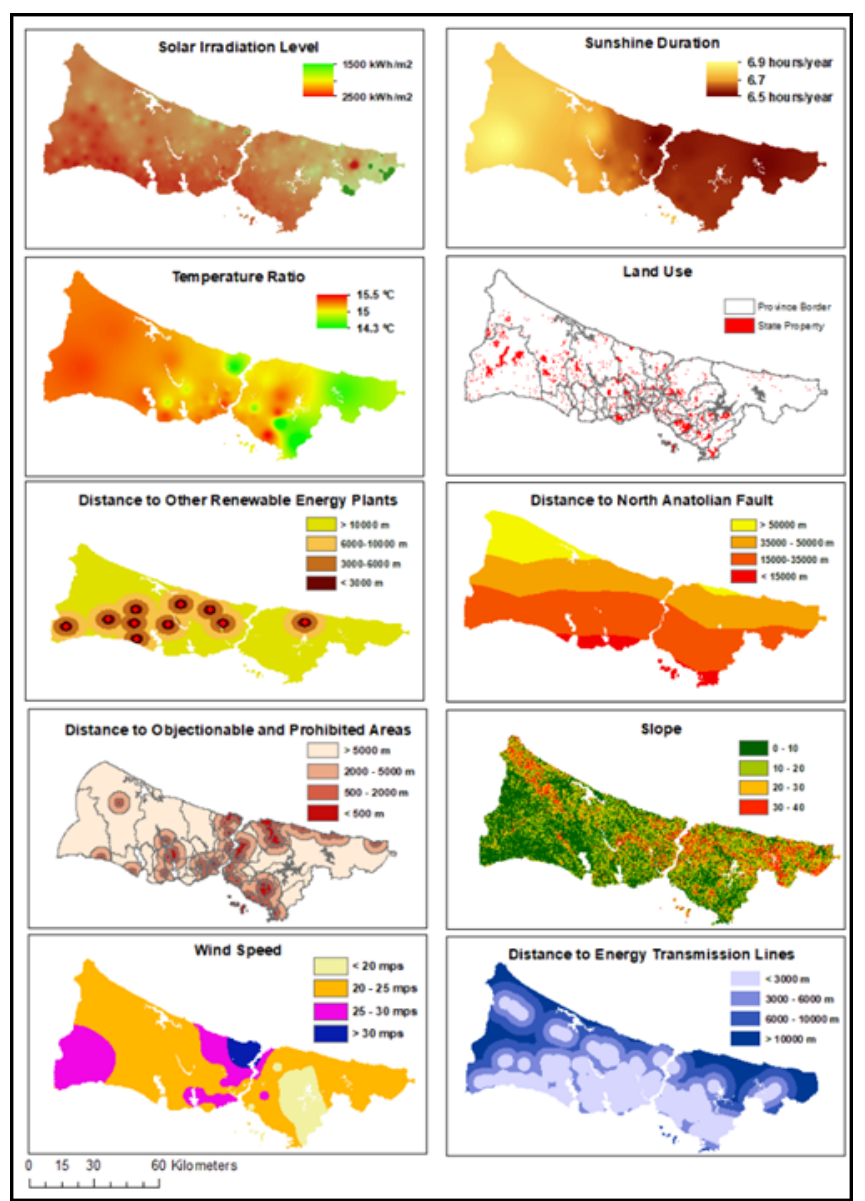

Figure 9. Weighted Criteria Maps

Also, spatial analysis carried out by overlapping areas with sufficiently large areas and vacant land, the areas where power plant construction can be started were obtained. At this point, the Istanbul Province Solar Power Plants Site Selection Availability Map (Figure 10), which was created, shows the multiplicity of areas suitable for Istanbul on the European side compared to the Asian side. When the size of the intersection areas in Figure 11 is evaluated, it is predicted that more individual panels will be suitable in these areas. However, the installation of large-scale solar power plants is possible in certain areas such as Şile and Büyükçekmece on both sides.

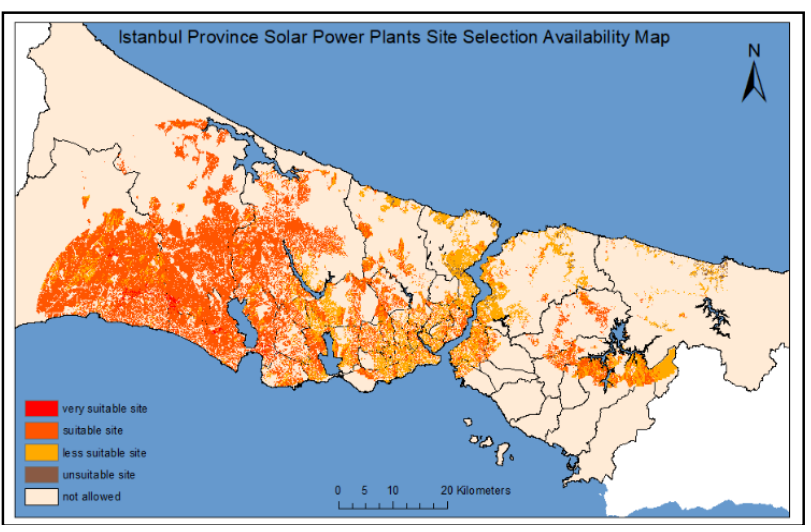

Figure 10. Istanbul Province Solar Power Plants Site Selection Availability Map
The sites have overall score in the range of $1.4-2.7$ in the overall weighted map are assigned to the highly suitable category for construction of solar power plants. The final site availability map for solar power plants in İstanbul is shown in Figure 10.

In the scope of the study, the areas which are in the form of a vacant land have been revealed with the help of the land use map created in previous studies for Istanbul province. At this point, the current (2018) building data and the vacant land data intersected to kept the results up to date. As a result, the map shown in Figure 11 is obtained.

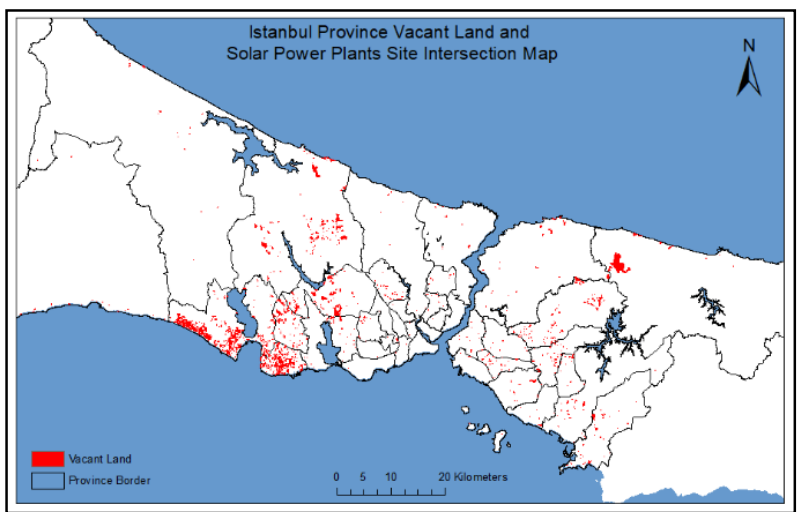

Figure 11. Istanbul Province Vacant Land and Solar Power Plants Site Intersection Map

The combined use of GIS and MCDM methods has provided great advantages in terms of management of multi-layered geographic data, regulation of benchmark weight and presentation of result product in appropriate format. Considering all, this study can be used as a resource for future studies. In addition, the Istanbul Province Vacant Land and Solar Power Plants Site Intersection Map, which is created as a result product, can be used as a basis for the development of renewable energy policies.

\section{REFERENCES}

Polat, S., \& Şekerci, H., 2011. Türkiye'nin yenilenebilir enerji konumu ve gelecek hedefleri (in Turkish). In Arch. III. Elektrik Tesisat Ulusal Kongre Ve Sergisi, Izmir, Türkiye. emo.org.tr/ekler/c7d4b893c29b329_ek.pdf (10 January 2019)

Karagöl E., \& Kavaz İ., 2017. Dünyada ve Türkiye'de yenilenebilir enerji. (in Turkish) In Arch. SETA Yayınlart ANALIZ, 197(1), 1-32. setav.org/assets/uploads/2017/04/Yen ilenebilirEnerji.pdf (10 January 2019)

Demir İ., \& Emeksiz C., 2016. Yenilenebilir enerji kaynaklarının Türkiye potansiyeli ve kullanımı (in Turkish). In Arch. ElektrikElektronik ve Bilgisayar Sempozyumu, Tokat, Turkey. researchgate.net/publication/311953029_Yenilenebilir _Enerji_Kaynaklarinin_Turkiye_Potansiyeli_ve_Kullanimi (10 January 2019)

Jackson T., 2000. Renewable energy sources. In Arch. Centre for Environmental Strategy, Working Paper- 07/00. surrey.ac.uk/sites/default/files/2018-03/07-00-renewableenergy-sources.pdf (10 January 2019) 
Selam A., Özel S., \& Arıoğlu Akan M., 2013. Yenilenebilir enerji kullanımı açısından Türkiye'nin OECD ülkeleri arasındaki yeri. (in Turkish) In Arch. T.R. Kutahya Dumlupinar University Journal of Social Sciences, (Special Issue), 317-334.

dergipark.gov.tr/download/article-file/360926(10 January 2019)

REN21., 2018. Renewables 2018 Global Status Report. REN21 Secretariat, Paris. ren21.net/wp-content/uploads/2018/06/178652_GSR2018_FullReport_web_final_.pdf (10 January 2019)

Saaty T. (2008). Decision making with the analytic hierarchy process, In Arch. International Journal of Services Sciences, 1(1), 83-98. rafikulislam.com/uploads/resourses/197245512559 a37aadea6d.pdf (10 January 2019)

Saner H., 2015. Türkiye'de güneş enerjisi santrallerinin yer seçimi ve çevresel etkileri: Karapınar ve Karaman enerji ihtisas endüstri bölgeleri örneklerinin değerlendirilmesi. (in Turkish) Unpublished master's thesis, Ankara University, Ankara, Turkey. acikarsiv.ankara.edu.tr/browse/27862/tez.pdf? show (10 January 2019)

Uyan M., 2016. GIS-supported mapping of solar power plant sites using AHP method. Pamukkale University Journal of Engineering Sciences, 23(4), 343-351. doi: 10.5505/pajes.2016.59489

Miller, A., \& Lumby, B., 2012. Utility scale solar power plants; a guide for developers and investors, International Finance Corporation-World Bank, New Delhi. tr.scribd.com/full screen/75218276? access key=key-18vdsrap7ejauw2nzbom

The Official Gazette of Turkey Number 30065., 2017. Rüzgar Veya Güneş Enerjisine Dayalı Üretim Tesisi Kurmak Üzere Yapılan Önlisans Başvurularına İlişkin Yarışma Yönetmeliği. (in Turkish) resmigazete.gov.tr/eskiler/2017/05/20170513-8.htm (10 January 2019)

Erduman, A., Kekezoğlu, B., Durusu, A., \& Tanrı̈oer, M., 2011. Yenilenebilir enerji kaynaklarından 500 kw'a kadar lisanssız enerji üretimi ve fizibilite analizi. (in Turkish) In Arch. ElektrikElektronik ve Bilgisayar Sempozyumu 2011, Elazı̆̆, Turkey. researchgate.net/publication/265376414_Yenilenebilir

Enerji Kaynaklarindan $500 \mathrm{~kW} \% 27 \mathrm{a}$ Kadar Lisanssiz Ener ji_Uretimi_ve_Fizibilite_Analizi (10 January 2019)

The Official Gazette of Turkey Number 25819., 2005. 5346 Sayılı Yenilenebilir Enerji Kaynaklarının Elektrik Enerjisi Üretimi Amaçlı Kullanımına İlișkin Kanun (5346 Law on Utilization of Renewable Energy Sources - in Turkish). resmigazete.gov.tr /eskiler/2005/05/20050518-1.html (10 May 2005)

The Official Gazette of Turkey Number 28809., 2013. Elektrik Piyasası Lisans Yönetmeliği (Electricity Market Licencing Regulation- in Turkish). resmigazete.gov.tr/eskiler/2013/11 /20131102-4.htm (2 November 2013)

The Official Gazette of Turkey Number 29033., 2014.

Rüzgar Ve Güneş Enerjisine Dayalı Önlisans Başvuruları İçin Yapılacak Rüzgar Ve Güneş Ölçümleri Uygulamalarına Dair Tebliğ. (Communiqué on Wind and Solar Measurements for Application of Wind and Solar Power Plant Pre-Licenses- in Turkish) resmigazete.gov.tr/eskiler/2014/06 /20140617-18.htm (17 June 2014)
The Official Gazette of Turkey Number 28896., 2014. Elektrik Piyasası Bağlantı Ve Sistem Kullanım Yönetmeliği (Regulation on Electricity Market Connetion and System Usage-in Turkish). resmigazete.gov.tr/eskiler/2014/01/20140128-30.htm (28 January 2018)

The Official Gazette of Turkey Number 28783.,2013. Elektrik Piyasasında Lisanssız Elektrik Üretimine İlişkin Yönetmelik (Regulation on Electricity Market Unlicenced Electricity Generation-in Turkish). resmigazete.gov.tr/eskiler/2013/10/201 31002-3.htm (2 October 2013)

The Official Gazette of Turkey Number 28229., 2012. Elektrik Piyasasında Lisanssız Elektrik Üretimine İlişkin Yönetmeliğin Uygulanmasına Dair Tebliğ (Communiqué on Application of Regulation on Electricity Market Unlicenced Electricity Generation-in Turkish). resmigazete.gov.tr/eskiler/2012/03/2 0120310-12.htm (10 March 2012).

Asakereh, A., Omid, M., Alimardani, R., \& Sarmadian, F. (2014). Developing a GIS-based Fuzzy AHP Model for Selecting Solar Energy Sites in Shodirwan Region in Iran.

Sindhu, S., Nehra, V., \& Luthra, S. (2017). Investigation of feasibility study of solar farms deployment using hybrid AHPTOPSIS analysis: Case study of India. Renewable and Sustainable Energy Reviews, 73, 496-511. doi:10.1016/j.rser.2017.01.135

Sánchez-Lozano, J. M., Henggeler Antunes, C., García-Cascales, M. S., \& Dias, L. C. (2014). GIS-based photovoltaic solar farms site selection using ELECTRE-TRI: Evaluating the case for Torre Pacheco, Murcia, Southeast of Spain. Renewable Energy, 66,478-494. doi: 10.1016/j.renene.2013.12.038

Akkaş, Ö.P., Erten, M.Y., Çam, \& E., İnanç, N. 2017. Optimal Site Selection for a Solar Power Plant in the Central Anatolian Region of Turkey. Hindawi International Journal of Photoenergy, doi : $10.1155 / 2017 / 7452715$

Uysal H., 2014. Selection of Logistics Centre Location via ELECTRE Method: A Case Study in Turkey. International Journal of Business and Social Science, 5(9), 276-289, https://ijbssnet.com/journals/Vol_5_No_9_August_2014/32.pdf

Algarni, H., \& Awasthi, A., 2017, Solar PV power plant site selection using a GIS-AHP based approach with application in Saudi Arabia, doi: 10.1016/j.apenergy.2017.10.024.

The Official Gazzette of Turkey Number 30110., 2017. Güneş Enerjisine Dayalı Elektrik Üretimi Başvurularının Teknik Değerlendirilmesi Hakkında Yönetmelik (Regulation on the Technical Evaluation of Applications for Generation of Electricity Based on Solar Energy - in Turkish). http://www.resmigazete.gov.tr/eskiler/2017/06/2017063010.htm (30 June 2017) 